\title{
NEW ANTI-CANDIDA ACTIVE NITROGEN-CONTAINING BISPHOSPHONATES AS INHIBITORS OF FARNESYL PYROPHOSPHATE SYNTHASE Candida albicans
}

\author{
L. O. METELYTSIA, D. M. HODYNA, O. L. KOBZAR, \\ V. V. KOVALISHYN, I. V. SEMENYUTA \\ V. P. Kukhar Institute of Bioorganic Chemistry and Petrochemistry, \\ National Academy of Sciences of Ukraine, Kyiv; \\ e-mail: ivan@bpci.kiev.ua
}

Received: 05 February 2019; Accepted: 14 March 2019

In our previous work, a number of new nitrogen-containing bisphosphonates (N-BPs) with high predicted and experimental antifungal activity were presented as potential Candida albicans farnesyl pyrophosphate synthase (FPPS) inhibitors. To confirm this hypothesis, a homologous C. albicans FPPS model with high-quality scores has been developed and used in present work to study the molecular mechanism of nitrogen-containing bisphosphonates action as anti-Candida agents. The known FPPS inhibitors ammonium 2-(Pyridin-2-ylamino)ethylidene-1,1-bisphosphonate, risedronate and alendronate were used in molecular docking analysis. The molecular docking analysis of the new $N$-BPs demonstrated a number of common features of all ligand's interaction in the active center of FPPS C. albicans. It is established that the ligands phosphonate groups are the key elements in the formation of the stable ligand-protein complexes with binding energy in a range $(\Delta G)$ from -6.6 to $-7.1 \mathrm{kcal} / \mathrm{mol}$ due to a significant number of electrostatic, hydrogen and metal-acceptor bonds. It is confirmed that the new studied N-BPS 1 and 3 with high anti-Candida activity are FPPS inhibitors.

Ke y w o r d s: nitrogen-containing bisphosphonates, farnesyl pyrophosphate synthase, Candida albicans, homology modeling, molecular docking.

I $t$ is known that several nitrogen-containing bisphosphonates (N-BPs) as the class of phosphorus compounds have important biomedical properties [1, 2]. Alendronate, ibandronate, risedronate created on their basis are effective drugs for such human skeletal system treatment as the Pedzhet's disease, primary hyperparathyreosis, myeloma, osteogenesis violations and malignant diseases of a bone tissue associated with the hypercalcemia [3, 4]. Moreover, $\mathrm{N}$-BPs have been established as promising candidate drugs for the treatment of pathogenic parasitic infections caused by Plasmodium spp., Leishmania major, Trypanosoma cruzi and other via the parasitic farnesyl pyrophosphate synthase (FPPS) inhibition $[5,6]$. N-BPs as the energy source are on parasitic acidocalciosomes for the calcium metabolism and for the supporting of the cell $\mathrm{pH}$ level [7].
On the other hand, FPPS of fungi, including C.albicans, takes part in the biosynthesis of ergosterol which is the main component of their cellular membrane [8].

In our previous work [9], it was assumed the functional similarity FPPS of microscopic fungi and parasitic protozoan as the organisms belonging to one Eucariota kingdom. In our work, the developed predictive QSAR models for the inhibition activities of N-BPs against FPPS from L. major using a data set of 97 compounds were presented. N-BPs with predictive activities were synthesized and estimated against $C$. albicans. The received experimental results of anti-Candida activity of the studied N-BPs confirmed the prediction results.

In the present study, we demonstrate the created homology FPPS C. albicans model and the

(C) 2019 Metelytsia L. A. et al. This is an open-access article distributed under the terms of the Creative Commons Attribution License, which permits unrestricted use, distribution, and reproduction in any medium, provided the original author and source are credited. 
docking analysis of active anti-Candida N-BPs into its active center as the confirmation of the earlier stated hypothesis.

\section{Materials and Methods}

All studied N-BPs (Scheme 1) [9] were screened for their in vitro activity against fungi C. albicans M 885 ATCC 10231 and its clinical fluconazole resistant isolate strains using the agar diffusion technique [10]. Compound 7 was synthesized and tested as a known FPPS L. major inhibitor [11]. Fluconazole (FL), as a known antifungal drug, was tested as a positive control. Two drugs, alendronate (AL) and risedronate (RS), were used as N-BPs with known FPPS inhibition activity [12] and antiparasitic properties [13]. The $0.5 \mathrm{McF}$ arland standard has been used as a reference to adjust the fungus suspensions turbidity and $1 \cdot 10^{9} \mathrm{CFU} / \mathrm{ml}$ (colony forming units in $1 \mathrm{ml}$ ) has been applied as a final cell inoculum.

The sequences of FPPS C. albicans (strain WO-1) (Yeast) (UniProt: C4YIE1) [14] and FPPS L. major (UniProtKB: Q4QBL1) [15] were used to create a homology model FPPS C. albicans. The amino acid sequence of FPPS C. albicans and L. major were aligned using the Needleman-Wunsch Global Align Protein Sequences (NCBI) [16] with applying BLOSUM-62 matrix and Gap costs $(11,1)$.

A preliminary search for evolutionarily related sequences was performed using the SWISS-MODEL Template Library (SWISS-MODEL server) [17]. The searching was conducted by BLAST [18] and HHBlits [19] for analysis of protein structures similar to FPPS C. albicans sequence. Homology models were created based on the results ranking of the tem- plates. ERRAT [20] and PROCHECK [21] were used to quality validation of FPPS C. albicans homology model.

Created homology model FPPS C. albicans was used for the protein-ligand docking studies conducted similarly to our earlier works [22, 23] using AutoDock Tools (ADT) (ver.1.5.6) [24]. The structure of FPPS A-subunit was selected and stored as a PDB file by Accelrys DS (ver. 2.5.5) [25]. Two $\mathrm{Mg}^{2+}$ ions and four water molecules which are part of the active center were added to the model (similarity to FPPS 4K10 (PDB: 4K10) [26]. Also, all protein hydrogens were added using ADT and no Bond Order method and the macromolecule atoms were renumbered. The calculated (by Gasteiger method) partial charges were added and the prepared protein structure was saved in PDBQT format.

The structures and conformations of studied ligands were obtained using ChemAxon Marvin Sketch 5.3.735 [27] and were saved in Mol2 format. The optimization of the ligands and energy minimization were performed by software Avogadro v1.1.1 [28]. "Auto Optimization Tool" was used by applying the MMFF94s force field and the steepest descent algorithm. Torsions angles and partial charges of ligands were changed by ADT and the ligand structures were saved in PDBQT format.

The prepared protein structure and optimized ligands were used for the docking analysis by $\mathrm{Au}-$ toDock Vina 1.1.2 [29]. The box center $(x=39.593$, $y=67.686, z=85.156$ ) was set into the ligand center of FPPS A-subunit $4 \mathrm{~K} 10$. The grid of $30 \times 30 \times 30$ points with grid spacing of $1.0 \AA$ was used. The software package Accelrys DS was used for the visuali-

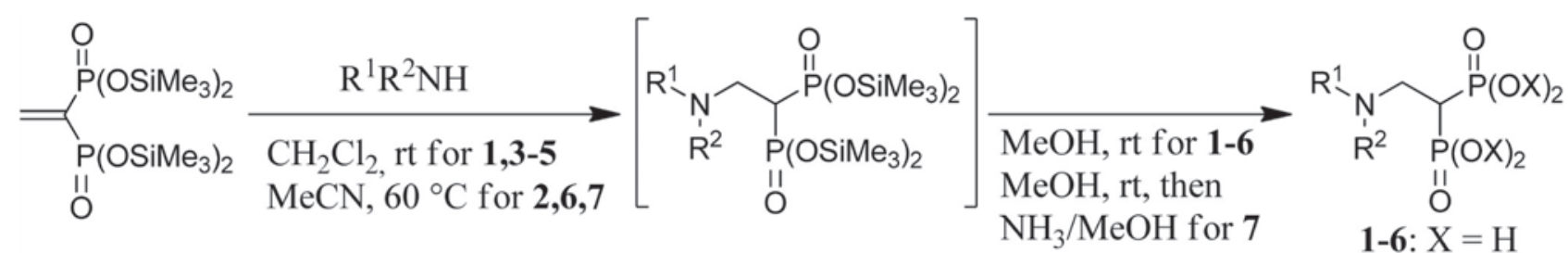

1: $\mathrm{R}^{1}=n-\mathrm{Bu} ; \mathrm{R}^{2}=\mathrm{H}$;

2: $\mathrm{R}^{1}=\mathrm{CHF}_{2}\left(\mathrm{CF}_{2}\right)_{3} \mathrm{CH}_{2} ; \mathrm{R}^{2}=\mathrm{H}$;

5: $\mathrm{R}^{1} \mathrm{R}^{2}=\left.\mathrm{EtO}_{\mathrm{O}}\right|_{\mathrm{N}} ^{\mathrm{N}}$

$7: \mathrm{R}^{1}=\mathrm{N}_{\mathrm{N}}$ ln $_{3} ; \mathrm{R}^{2}=\mathrm{H}$;

1-6: $\mathrm{X}=\mathrm{H}$

3: $\mathrm{R}^{1}=c-\mathrm{C}_{6} \mathrm{H}_{11} ; \mathrm{R}^{2}=\mathrm{H}$;

$4: \mathrm{R}^{1}=\overbrace{\mathrm{N}} ; \mathrm{R}^{2}=\mathrm{H}$;

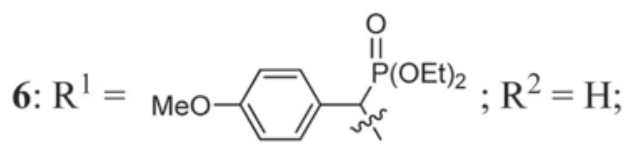

Scheme 1. Synthesis of N-BPs 1-7 
zation and the analysis of the protein-ligand interactions.

\section{Results and Discussions}

Results of testing of N-BPs are presented in the Table. The data presented in Table show that compounds 1 and 3 exhibit highest activity against sensitive C. albicans M 885 ATCC 10231 strain and its resistant clinical isolate. Zones of inhibition formed by these compounds under conditions of high microbial loading as $1 \cdot 10^{9}$ colony forming units (CFU) in $1 \mathrm{ml}$ significantly exceeded those formed using FL (a known antifungal drug) both against sensitive fungi strain and against drug-resistant clinical isolate of C. albicans. Both studied strains were sensitive to drugs alendronate and risedronate which are known FPPS inhibitors applied at the treatment of human skeletal system and pathogenic parasitic infections and against compound 7 as known inhibitors of FPPS L. major.

The received experimental research results indicate a molecular action mechanism of N-BPs associated with FPPS C. albicans.

Further researches were conducted using docking analysis of active N-BPs 1, 3 and known FPPS inhibitors 7, alendronate and risedronate in the active site of FPPS C. albicans homology model.

Protein sequences FPPSs $C$. albicans and L. major were investigated and compared using Protein BLAST (NCBI) and such operating parameters as the substitution Matrix (BLOSUM-62) and Gap Costs (11,1) (Fig. 1).

The obtained results (Fig. 1) indicate the significant similarity of the enzymes primary structure. So, the sequence identity was $34 \%$, the sequence similarity was $53 \%$ and a number to gaps was 5\%.The secondary structure similarity, the binding sites and the active sites of FPPSs were studied by Accelrys DS (Fig. 2).

Fig. 2 has demonstrated a significant similarity also a secondary structure of enzymes. The similarity is noted in the area of $\mathrm{Mg}^{2+}$ binding sites, active sites and substrate binding sites. The creation of a homology model was begun with a preliminary search of sequences related to the FPPS using the SWISS-MODEL template library and 50 templates were generated. The template 4K10.1.A was used for developing of the homology model of FPPS C. albicans (Fig. 3).

Created model is optimal considering the values of resolution (2.3 $\AA$ ), QMEAN (-2.16), GMQE (0.73), GSQE (0.83) indicators. The quality estimation of the built FPPS C. albicans model was conducted by ERRAT and PROCHECK. ERRAT-web server results showed high model quality. The overall quality factor for the subunit A was 94.260 and for the subunit B was 96.049 (Fig. 4).

PROCHECK-web server analysis has also been confirmed the good quality of 3D model FPPS by using Ramachandran plot analysis (Fig. 5).

Activity (inhibition zone diameters, $\mathrm{mm}$ ) of studied $\mathrm{N}$-BPs against fungi C. albicans strains

\begin{tabular}{c|cc|c|c|c|c}
\hline \multirow{2}{*}{ Compounds } & \multicolumn{6}{|c}{ The microbial loading, CFU in ml } \\
\cline { 2 - 7 } & \multicolumn{2}{|c}{$1 \cdot 10^{7}$} & \multicolumn{2}{c}{$1 \cdot 10^{8}$} & \multicolumn{2}{c}{$1 \cdot 10^{9}$} \\
\cline { 2 - 7 } & $\begin{array}{c}\text { C. albicans } \\
\text { (ATCC) }\end{array}$ & $\begin{array}{c}\text { C. albicans } \\
\text { (isolate) }\end{array}$ & $\begin{array}{c}\text { C. albicans } \\
\text { (ATCC) }\end{array}$ & $\begin{array}{c}\text { C. albicans } \\
\text { (isolate) }\end{array}$ & $\begin{array}{c}\text { C. albicans } \\
\text { (ATCC) }\end{array}$ & $\begin{array}{c}\text { C. albicans } \\
\text { (isolate) }\end{array}$ \\
\hline $\mathbf{1}$ & $24.4 \pm 0.8$ & $22.1 \pm 0.5$ & $21.2 \pm 0.3$ & $20.4 \pm 0.4$ & $19.6 \pm 0.4$ & $17.7 \pm 0.3$ \\
$\mathbf{2}$ & $8.6 \pm 0.2$ & NA & NA & NA & NA & NA \\
$\mathbf{3}$ & $21.4 \pm 0.7$ & $20.1 \pm 0.6$ & $21.1 \pm 0.3$ & $18.8 \pm 0.3$ & $19.6 \pm 0.5$ & $16.9 \pm 0.4$ \\
$\mathbf{4}$ & $8.7 \pm 0.2$ & NA & NA & NA & NA & NA \\
$\mathbf{5}$ & NA & NA & NA & NA & NA & NA \\
$\mathbf{6}$ & NA & NA & NA & NA & NA & NA \\
$\mathbf{7}$ & $22.6 \pm 0.6$ & $19.8 \pm 0.3$ & $20.2 \pm 0.6$ & $17.7 \pm 0.5$ & $18.7 \pm 0.4$ & $16.9 \pm 0.4$ \\
FL & $20.5 \pm 0.5$ & NA & $18.4 \pm 0.5$ & NA & $12.6 \pm 0.6$ & NA \\
RS & $19.8 \pm 0.3$ & $16.6 \pm 0.5$ & $17.7 \pm 0.4$ & $15.1 \pm 0.5$ & $17.6 \pm 0.4$ & $13.3 \pm 0.3$ \\
AL & $19.5 \pm 0.4$ & $17.4 \pm 0.6$ & $18.5 \pm 0.3$ & $15.6 \pm 0.5$ & $18.3 \pm 0.4$ & $14.1 \pm 0.4$ \\
\hline
\end{tabular}

Note: contents of all compounds on a disk was $0.1 \mu \mathrm{M}, \mathrm{NA}-$ no activity 


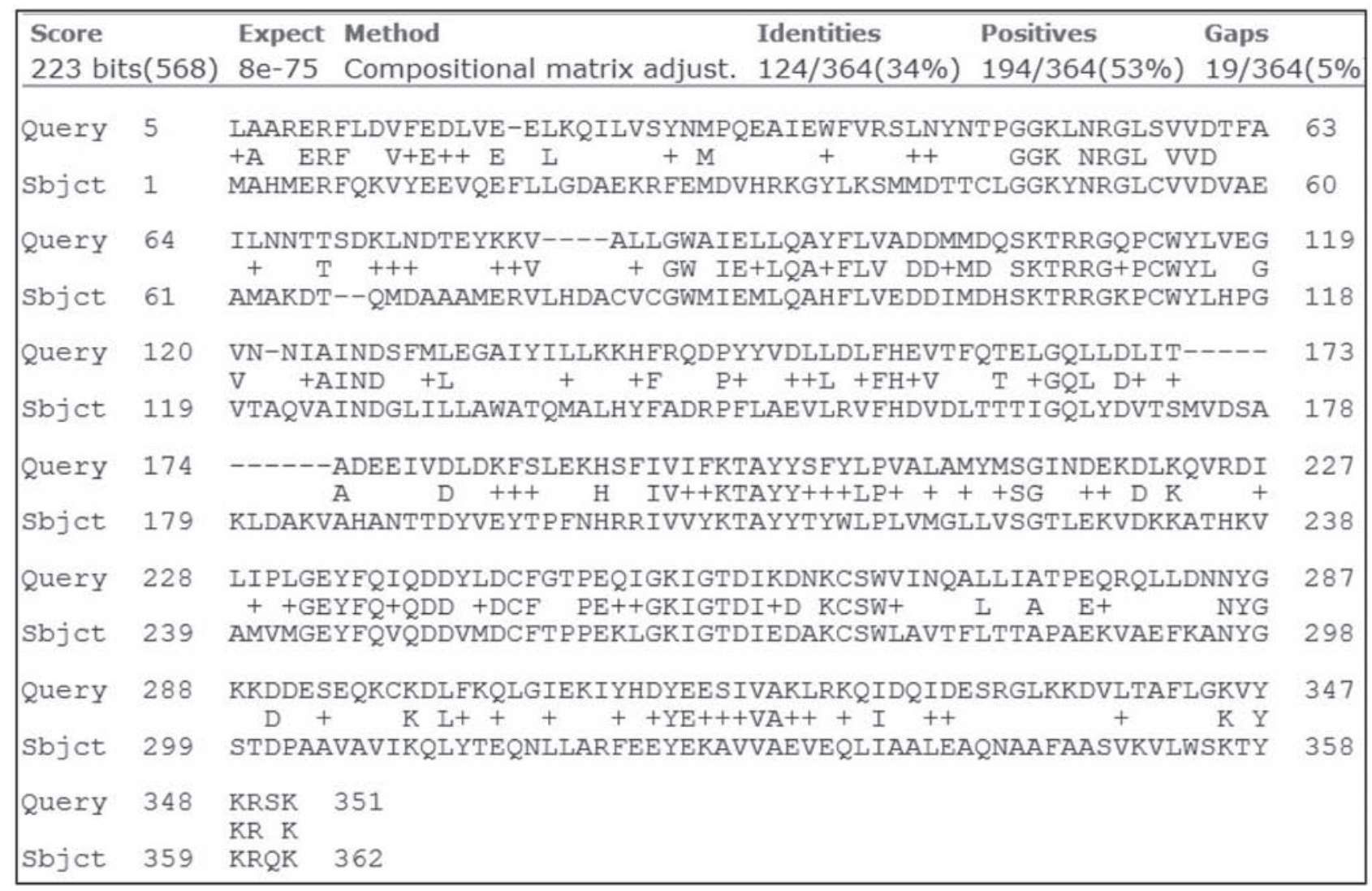

Fig. 1. Protein BLAST results of FPPS C. albicans and FPPS L. major by application of Needleman-Wunsch Global Align Protein Sequences

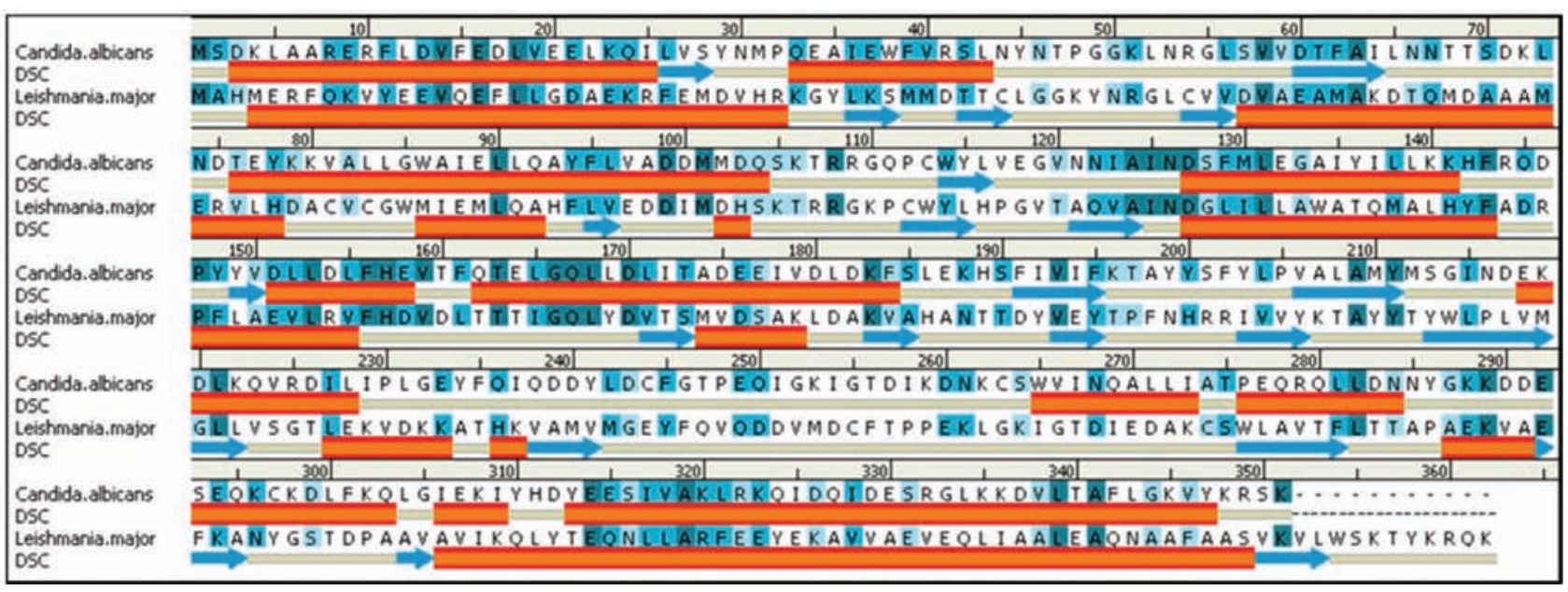

Fig. 2. A comparison of secondary structure, binding sites and active sites of FPPS C. albicans and FPPS L. major by Accelrys DS, red- $\alpha$-helixes, blue - $\beta$-sheets and gray - disordered regions

Ramachandran plot results indicated that $91.5 \%$ of the protein residues were distributed in the favored regions, $6.9 \%$ - in the additionally allowed regions, $1.1 \%$ - in the generously allowed regions and $0.5 \%$ - in the disallowed region. Thus, the created
3D structure of FPPS C. albicans is adequate and was used for the molecular docking.

Molecular docking of the compounds 1, 3 into the active site of FPPS was performed to mechanism interpretation of their high antifungal activity. Com- 


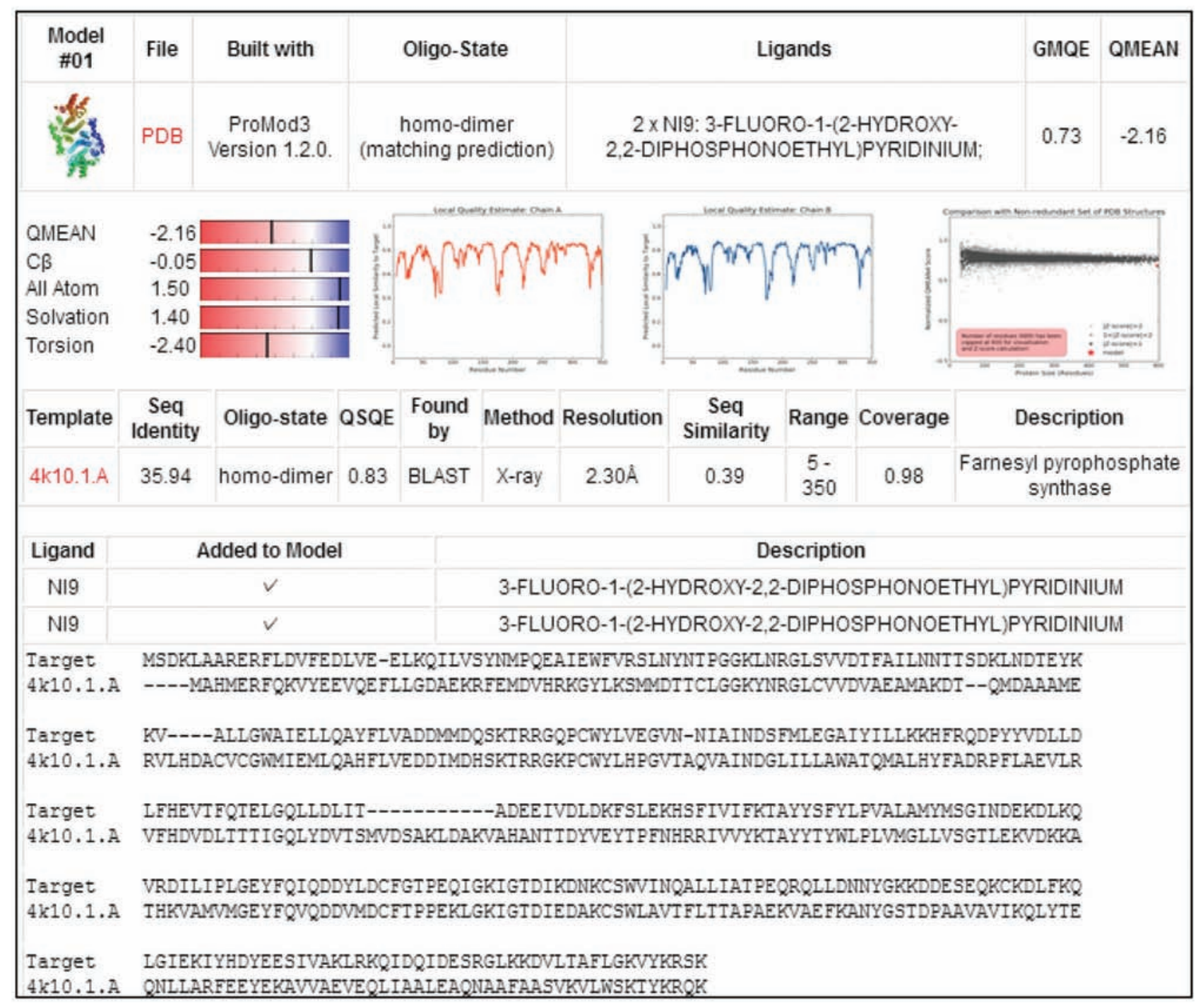

Fig. 3. Quality of the built model FPPS C. albicans

pound 7 was docked as a known FPPS L. major inhibitor, alendronate and risedronate - as N-BPs with known FPPS inhibition activity and antiparasitic properties (Fig. 6-10).

Fig. 6 data showed that one of the phosphonate groups forms the four electrostatic bonds (3.10$5.45 \AA$ ) with a catalytic magnesium ion and amino acid residues Asp99, Arg108, Asp239 the one metalacceptor bond with magnesium ion and the three hydrogen bonds (2.26-2.45 $\AA$ ) with two water molecules.

The other phosphonate group forms the seven electrostatic bonds (3.12-5.57 $\AA$ ) with a catalytic magnesium ion and amino acid residues Asp99, Asp170, Lys196, Asp257, Lys262, the one metalacceptor bond (2.67 $\AA$ ) with magnesium ion and the three hydrogen bonds (2.02-3.08 $\AA$ ) with two water molecules and the amino acid residue Lys196.
Also, the amino group of the ligand forms an electrostatic bond (3.24 $\AA$ ) with the amino acid Asp99.

Fig. 7 showed that the one phosphonate group forms the six electrostatic bonds (3.20-5.58 $\AA$ ) with a catalytic magnesium ion and amino acid residues Asp99, Arg108, Asp239, Lys253, and the four hydrogen bonds (2.42-3.03 $\AA$ ) with two water molecules and the amino acid Arg108.

The other phosphonate group forms the nine electrostatic bonds (2.98-5.15 $\AA$ ) with catalytic magnesium ions and amino acid residues Asp99, Lys196, Lys262, the one metal-acceptor bond (2.81 $\AA$ ) with a magnesium ion and the four hydrogen bonds (2.04$3.03 \AA$ ) with the three water molecules and the amino acid residue Lys196. 
Program: ERRAT2

Chain: A

Overall quality factor*: 94.260

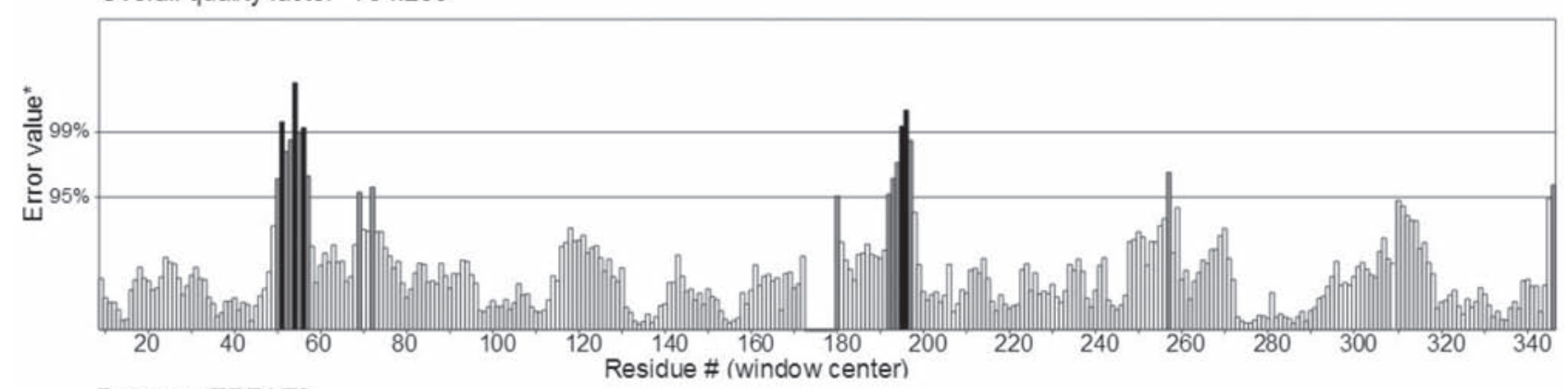

Program: ERRAT2

Chain: B

Overall quality factor ${ }^{\star \star}: 96.049$

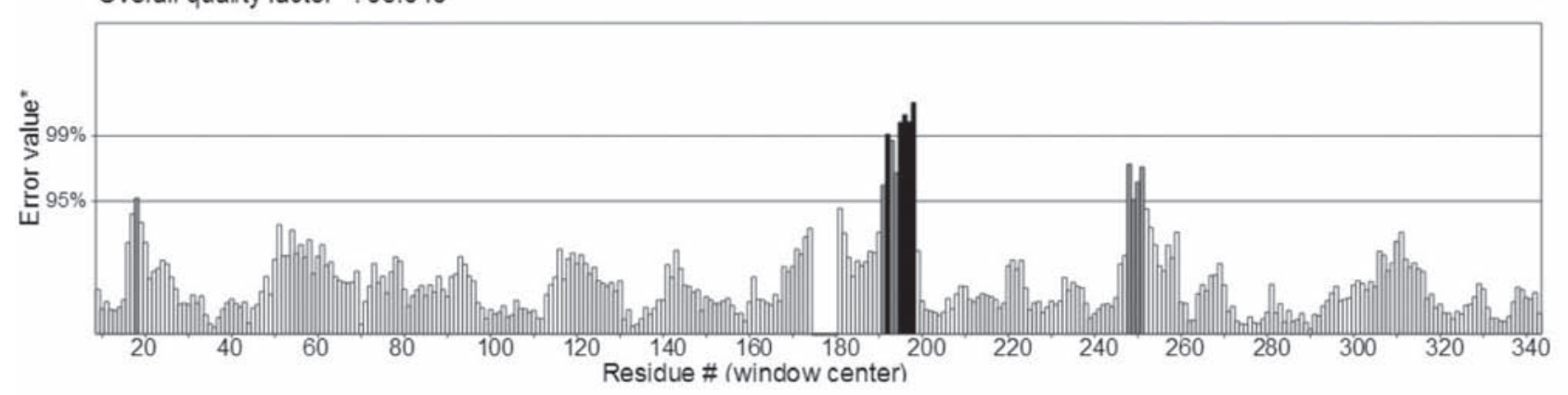

Fig. 4. The 3D profile of subunit A and B of FPPS C. albicans verified using ERRAT server

Also, the cyclohexyl group of the ligand forms the two hydrophobic bonds - Pi-alkyl (5.15 $\AA$ ) and Alkyl (4.84 $\AA$ ) with the amino acids Lys196 and Phe95.

Molecular docking results (Fig. 8) showed that the one phosphonate group forms the seven electrostatic bonds (3.03-5.33 $\AA$ ) with catalytic magnesium ions and Asp99, Arg108, Lys196 amino acid residues, and the one metal-acceptor bond (3.15 $\AA$ ) with a magnesium ion and the four hydrogen bonds (2.13$2.77 \AA$ ) with the four water molecules.

The other phosphonate group forms the six electrostatic bonds (4.26-5.49 $\AA$ ) with a catalytic magnesium ion and the amino acid residues Arg108, Asp239, Arg254, and the one hydrogen bond (2.87 $\AA$ ) with Arg108.

The pyridine ligand cycle forms a hydrophobic Pi-alkyl bond (4.87 $\AA$ ) and an electrostatic Pi-cation bond (4.98 $\AA$ ) with the amino acid Lys196.

Docking results (Fig. 9) showed that the one phosphonate group forms the six electrostatic bonds (3.09-5.49 $\AA$ ) with catalytic magnesium ions and amino acid residues Arg108, Lys253, the one metalacceptor bond (3.03 $\AA$ ) with magnesium ion and the two hydrogen bonds (2.20-2.52 $\AA$ ) with the two water molecules.

The other phosphonate group forms the four electrostatic bonds (2.98-5.56 $\AA$ ) with a catalytic magnesium ion and the amino acid residues Asp99, Lys196, Lys262, and the three hydrogen bonds (1.903.23 A) with the two water molecules and Lys196.

Also, the hydroxyl ligand group forms a hydrogen bond (3.07 $\AA$ ) with the amino acid residue Asp99.

And the ligand pyridine cycle forms a hydrogen bond (3.37 $\AA$ ) with Asp99 and a hydrophobic Pi-alkyl bond ( $5.15 \AA$ ) and an electrostatic Pi-cation bond (4.66 §) with Asp99.

Docking of alendronate (Fig. 10) demonstrated that the one phosphonate group forms the five electrostatic bonds (3.03-5.58 $\AA$ ) with a catalytic magnesium ion and Asp99, Asp170, Lys262, and the five hydrogen bonds (1.90-3.34 $\AA$ ) with the two water molecules and Lys196, Lys262.

The second phosphonate group forms the five electrostatic bonds (3.84-5.49 $\AA$ ) with a catalytic magnesium ion and amino acid residues Asp99, Arg108, Asp239, Lys253, the one metal-acceptor 
PROCHECK

Ramachandran Plot 7921457

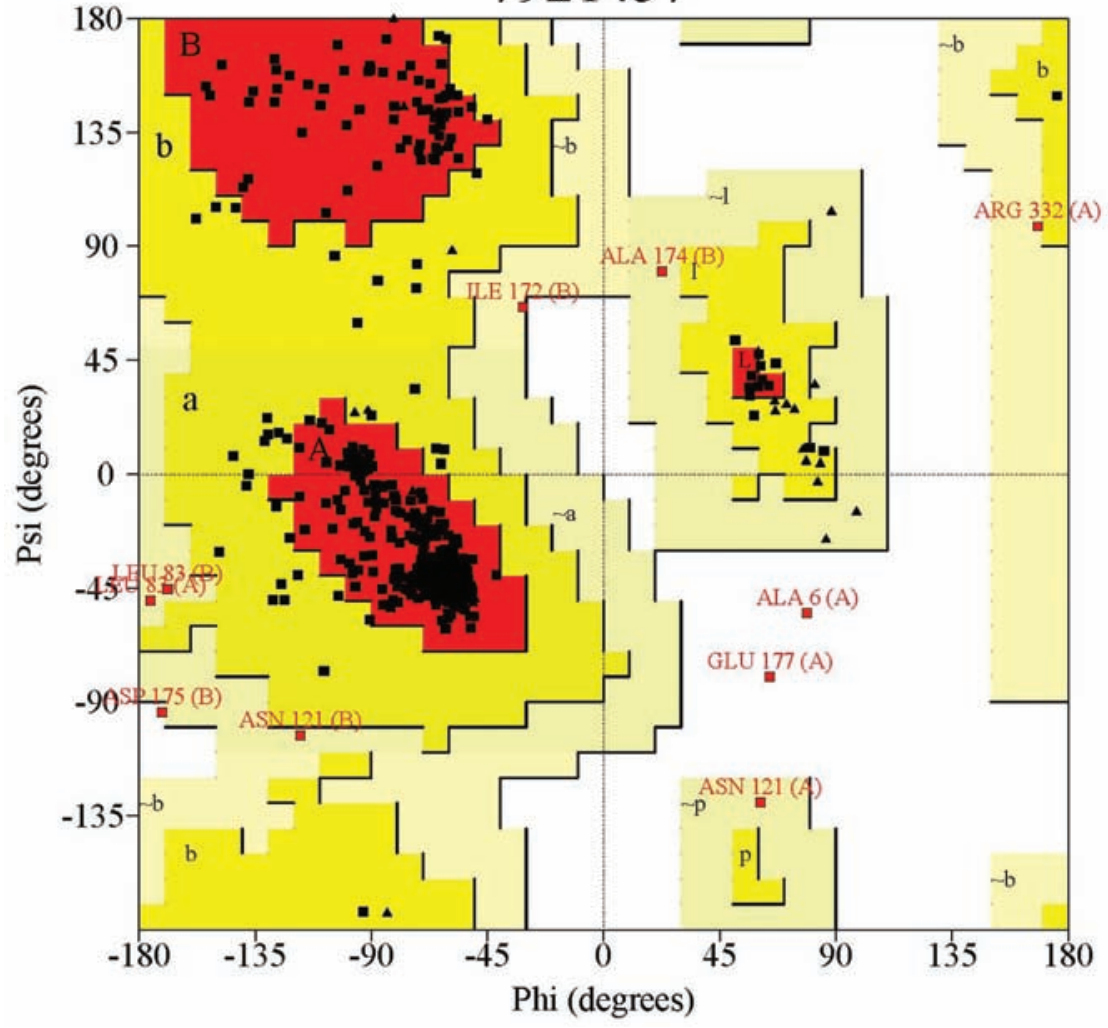

Plot statistics

\begin{tabular}{|c|c|c|}
\hline Residues in most favoured regions $[\mathrm{A}, \mathrm{B}, \mathrm{L}]$ & 581 & $91.5 \%$ \\
\hline Residues in additional allowed regions $[\mathrm{a}, \mathrm{b}, 1, \mathrm{p}]$ & 44 & $6.9 \%$ \\
\hline Residues in generously allowed regions $[\sim a, \sim b, \sim 1, \sim p]$ & 7 & $1.1 \%$ \\
\hline Residues in disallowed regions & 3 & $0.5 \%$ \\
\hline Number of non-glycine and non-proline residues & 635 & $100.0 \%$ \\
\hline Number of end-residues (excl. Gly and Pro) & 6 & \\
\hline Number of glycine residues (shown as triangles) & 34 & \\
\hline Number of proline residues & 16 & \\
\hline Total number of residues & 691 & \\
\hline
\end{tabular}

Fig. 5. Ramachandran plot results of the stereochemical quality of the FPPS C.albicans model generated by PROCHECK validation server

bond (3.05 $\AA$ ) with a magnesium ion and the four hydrogen bonds (2.26-3.15 $\AA$ ) with the two water molecules and Arg108.

The hydroxyl ligand group forms the two hydrogen bonds (2.65, $3.03 \AA$ ) with the water molecule and Asp99.

The amino group of the ligand forms the two hydrogen bonds (2.89, $2.98 \AA$ ) with Thr197 and Gln236.

A homology FPPS C.albicans model with high-quality scores has been developed and pre- sented to confirmation of the molecular mechanism action of new nitrogen-containing bisphosphonates as anti-Candida agents. Molecular docking analysis of the studied compounds was performed based on the analysis of such known FPPS inhibitors as ammonium 2-(Pyridin-2-ylamino)ethylidene-1,1bisphosphonate, risedronate and alendronate. The molecular docking results demonstrated a number of common features of the ligand's interaction into the active center FPPS $C$ albicans. Thus, the phosphonate groups of all ligands are key elements in the 


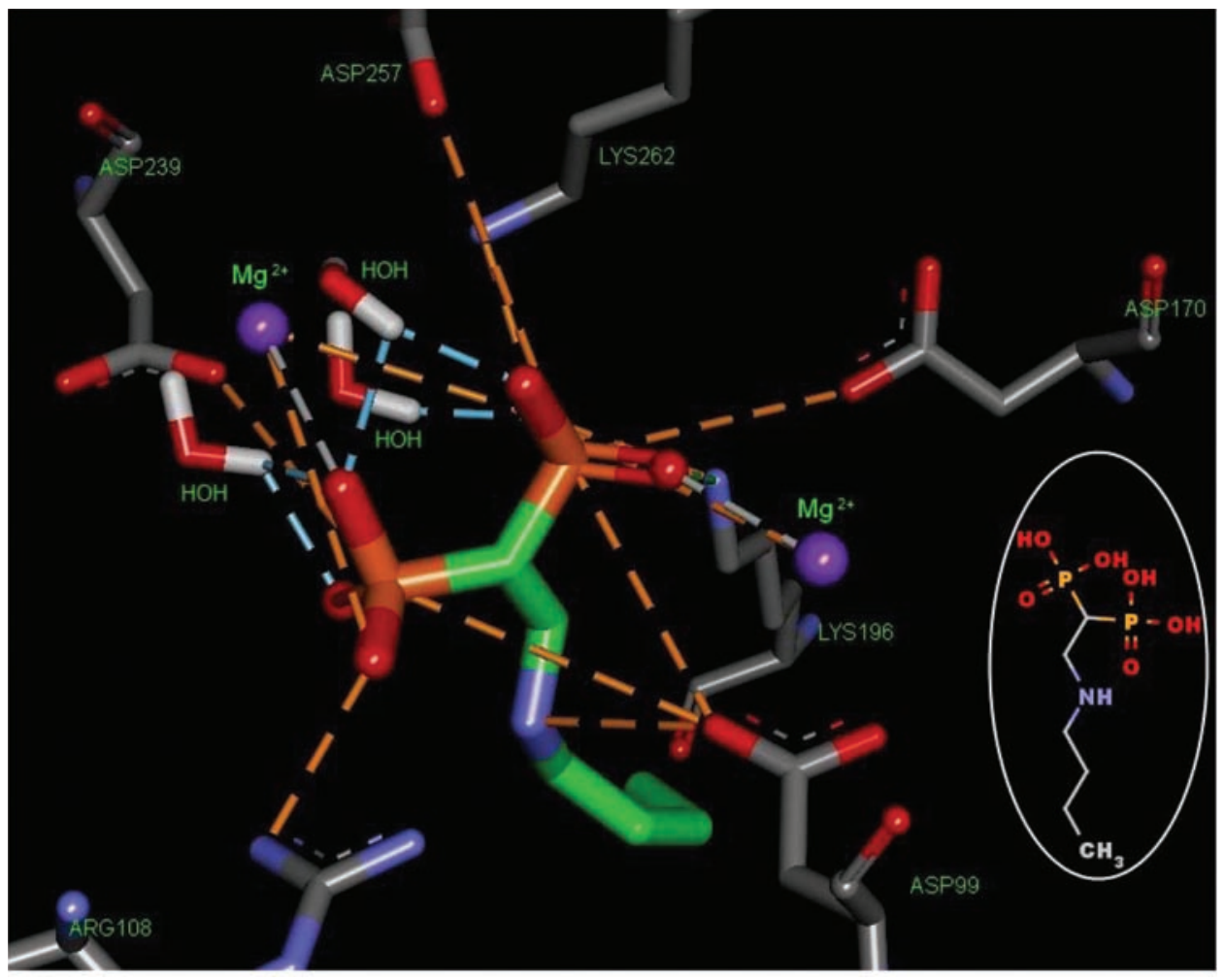

Fig. 6. Molecular docking of compound 1 into the active site of FPPS C. albicans

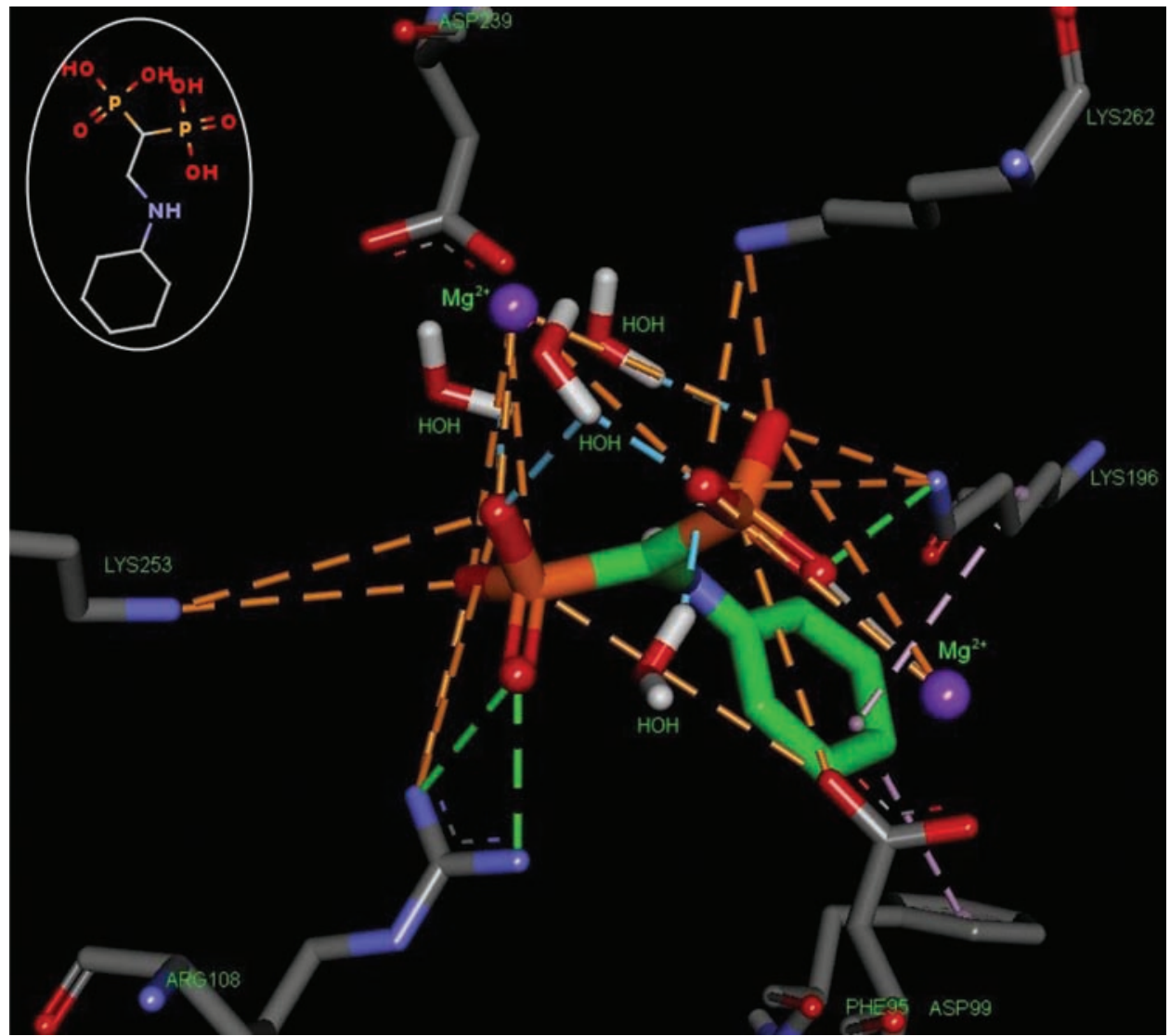

Fig. 7. Molecular docking of compound 3 into the active site of FPPS C. albicans 


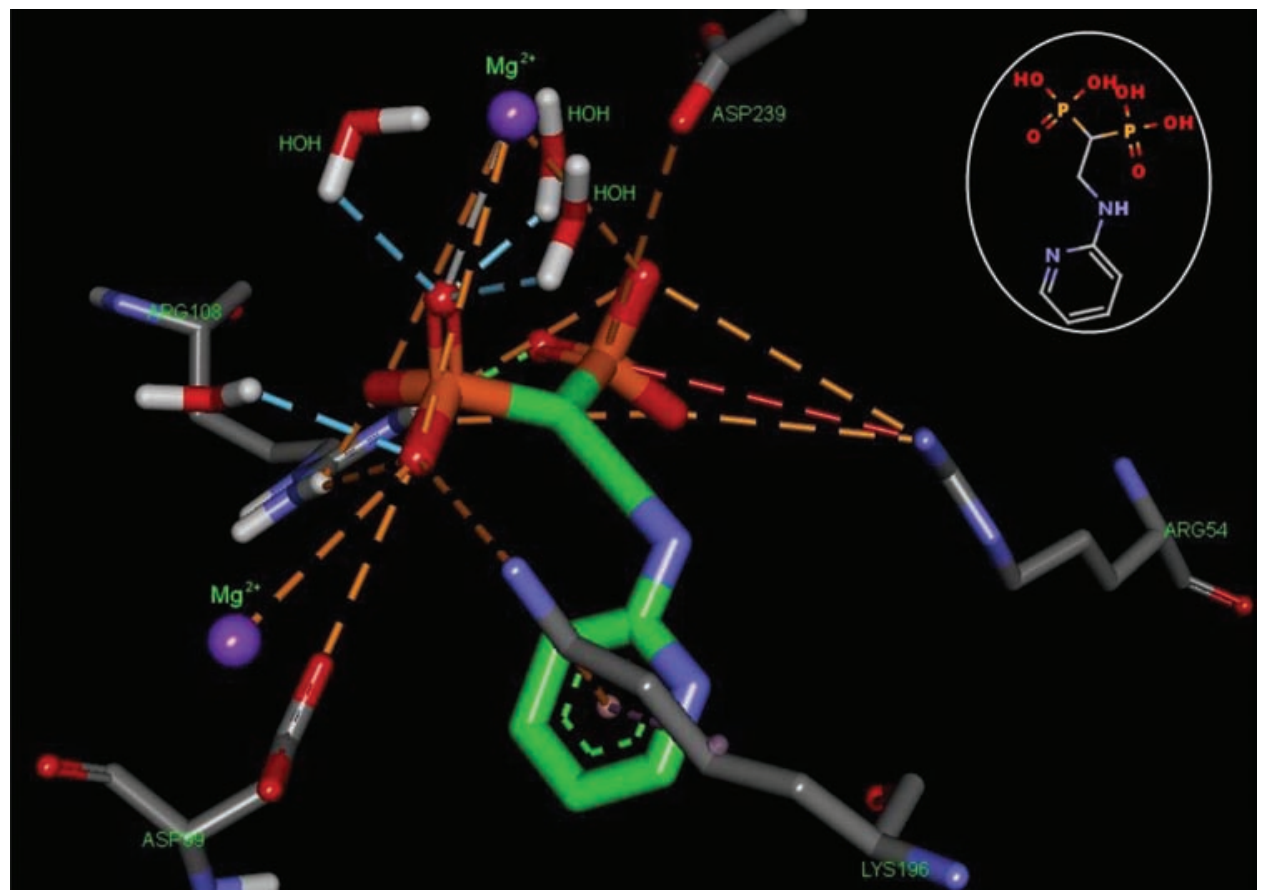

Fig. 8. Molecular docking of compound 7 into the active site of FPPS C. albicans

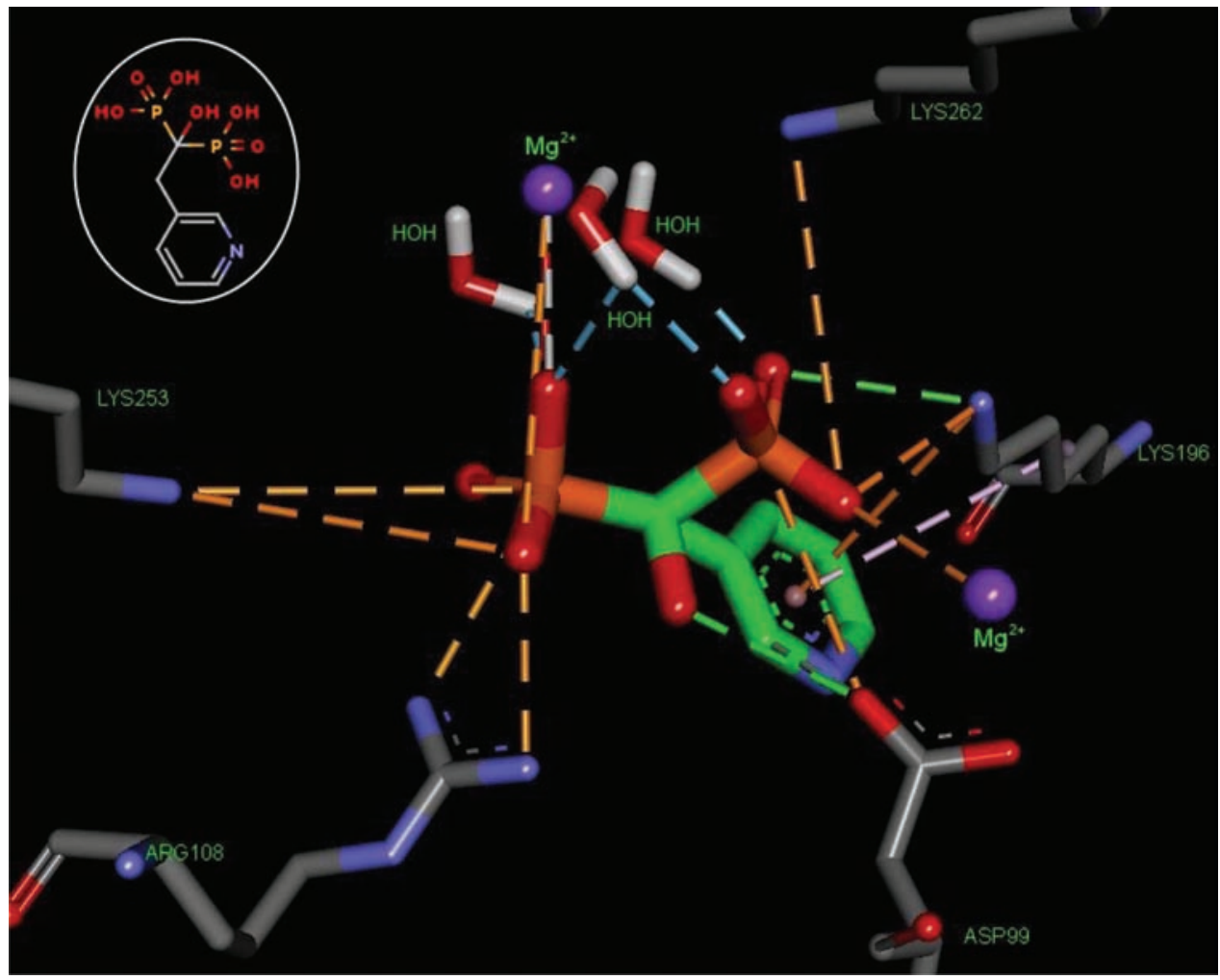

Fig. 9. Molecular docking of risedronate into the active site of FPPS C. albicans 


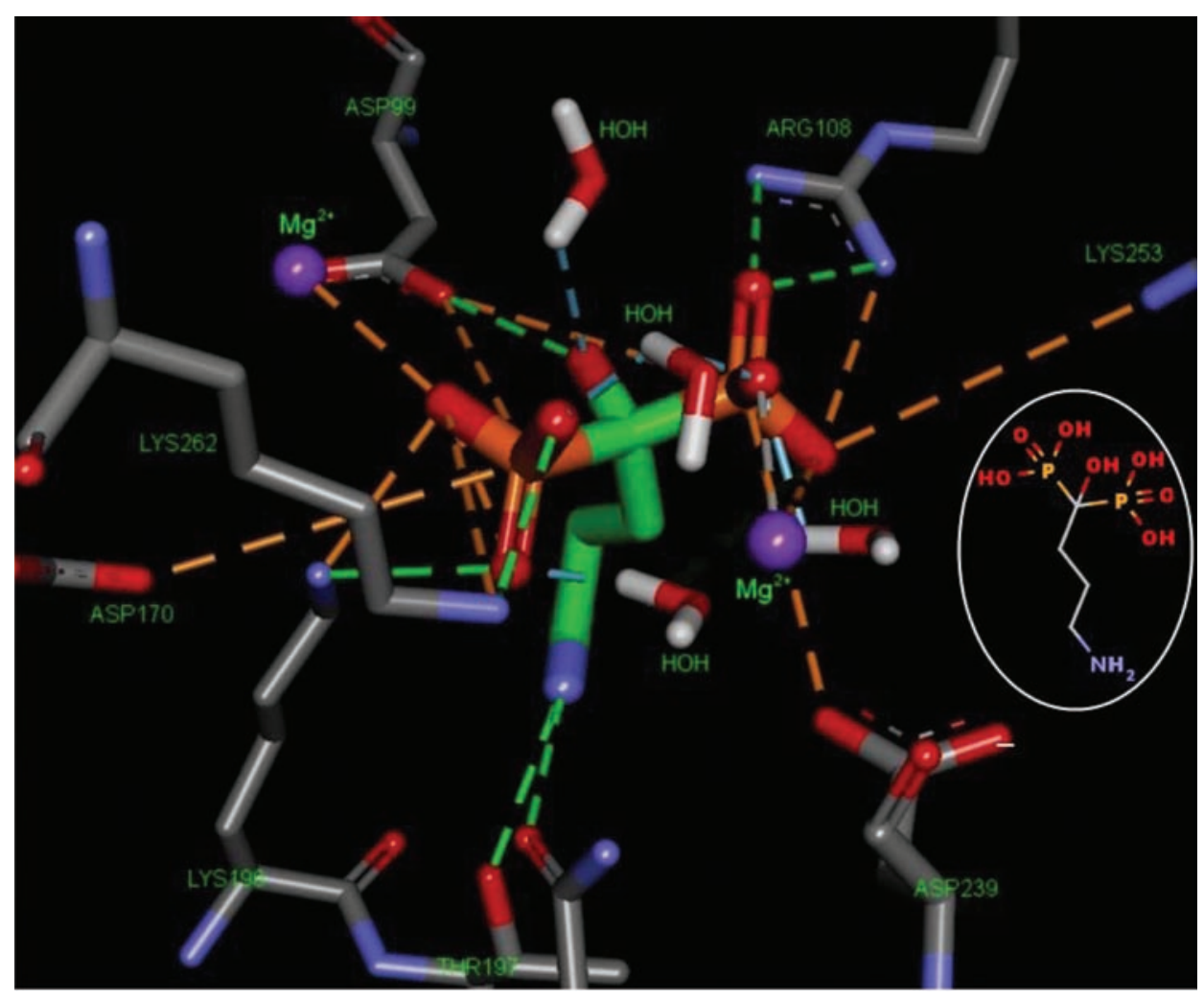

Fig. 10. Molecular docking of alendronate into the active site of FPPS C. albicans

formation of stable ligand-protein complexes due to a significant number of electrostatic, hydrogen and metal-acceptor bonds. The formed high stability of ligand-protein complexes demonstrated the binding energy in range $(\Delta \mathrm{G})$ from -6.6 to $-7.1 \mathrm{kcal} / \mathrm{mol}$. The amino acid residues Asp99, Arg108, Lys196, Lys253, Lys262, catalytic magnesium ions and water molecules were a key in the ligand-protein complexes creation. Thus, our studies have shown that the new studied compounds with high anti-Candida activity are FPPS inhibitors.

Conflict of interest. Authors have completed the Unified Conflicts of Interest form at http:// ukrbiochemjournal.org/wp-content/uploads/2018/12/ coi_disclosure.pdf and declare no conflict of interest. 


\section{АНТИКАНДИДОЗНА АКТИВНІСТЬ НОВИХ НІТРОГЕНВМІСНИХ БІСФОСФОНАТІВ ЯК ІНГІБІТОРІВ ФАРНЕЗИЛПІРОФОСФАТ-СИНТАЗИ Candida albicans}

\section{Л. О. Метелиия, Д. М. Година, О. Л. Кобзар, В. В. Ковалішин, I. В. Семенюта}

\author{
Інститут біоорганічної хімії та нафтохімії \\ ім. В. П. Кухаря НАН України, Київ; \\ e-mail: ivan@bpci.kiev.ua
}

У нашій попередній роботі було представлено низку нових нітрогенвмісних бісфосфонатів (N-БФ) з високою передбаченою та експериментальною протигрибковою активністю як потенційні інгібітори фарнезилпірофосфатсинтази (ФПФС) Candida albicans. Щоб підтвердити цю гіпотезу було розроблено гомологічну модель ФПФС C. albicans із високими показниками якості і використано в цій роботі для вивчення молекулярного механізму дії активних N-БФ як антикандидозних агентів. Амоній-2-(піридин-2іламіно) етиліден-1,1-бісфосфонатів, різедронат i алендронат використовували в молекулярному докінгу як відомі інгібітори ФПФС. Молекулярний докінг нових N-БФ продемонстрував низку загальних закономірностей взаємодії всіх лігандів в активному центрі ФПФС C. albicans. Встановлено, що фосфонатні групи всіх лігандів $\epsilon$ ключовими елементами в утворенні стабільних ліганд-протеїнових комплексів 3 енергією зв'язку в діапазоні $(\Delta \mathrm{G})$ від -6,6 до -7,1 ккал/моль завдяки значній кількості електростатичних, водневих і металакцепторних зв'язків. Було підтверджено, що нові вивчені N-БФ 1 і 3 з високою протикандидозною активністю $є$ інгібіторами ФПФС.

К л ю ч о в і с л о в а: нітрогенвмісні бісфосфонати, фарнезилпірофосфатсинтаза, Candida albicans, гомологічне моделювання, молекулярний докінг.

\section{References}

1. Giger EV, Castagner B, Leroux JC. Biomedical applications of bisphosphonates. $J$ Control Release. 2013; 167(2): 175-188.

2. Coleman R. The use of bisphosphonates in cancer treatment. Ann N Y Acad Sci. 2011; 1218(1): 3-14.
3. Fraunfelder FW. Ocular side effects associated with bisphosphonates. Drugs Today (Barc). 2003; 39(11): 829-835.

4. Grey A, Reid IR. Differences between the bisphosphonates for the prevention and treatment of osteoporosis. Ther Clin Risk Manag. 2006; 2(1): 77-86.

5. Martin MB, Grimley JS, Lewis JC, Heath HT 3rd, Bailey BN, Kendrick H, Yardley V, Caldera A, Lira R, Urbina JA, Moreno SN, Docampo R, Croft SL, Oldfield E. Bisphosphonates inhibit the growth of Trypanosoma brucei, Trypanosoma cruzi, Leishmania donovani, Toxoplasma gondii, and Plasmodium falciparum: a potential route to chemotherapy. J Med Chem. 2001; 44(6): 909916.

6. Yardley V, Khan AA, Martin MB, Slifer TR, Araujo FG, Moreno SN, Docampo R, Croft SL, Oldfield E. In vivo activities of farnesyl pyrophosphate synthase inhibitors against Leishmania donovani and Toxoplasma gondii. Antimicrob Agents Chemother. 2002; 46(3): 929931.

7. Docampo R, Moreno SN. Bisphosphonates as chemotherapeutic agents against trypanosomatid and apicomplexan parasites. Curr Drug Targets Infect Disord. 2001; 1(1): 51-61.

8. Hornby JM, Kebaara BW, Nickerson KW. Farnesol biosynthesis in Candida albicans: cellular response to sterol inhibition by zaragozic acid B. Antimicrob Agents Chemother. 2003; 47(7): 2366-2369.

9. Prokopenko V, Kovalishyn V, Shevchuk M, Kopernyk I, Metelytsia L, Romanenko V, Mogilevich S, Kukhar V. Design and synthesis of new potent inhibitors of farnesyl pyrophosphate synthase. Curr Drug Discov Technol. 2014; 11(2): 133-144.

10. Bauer AW, Kirby WM, Sherris JC, Turck M. Antibiotic susceptibility testing by a standardized single disk method. Am J Clin Pathol. 1966; 45(4): 493-496.

11. Sanders JM, Gómez AO, Mao J, Meints GA, Van Brussel EM, Burzynska A, Kafarski P, González-Pacanowska D, Oldfield E. 3-D QSAR investigations of the inhibition of Leishmania major farnesyl pyrophosphate synthase by bisphosphonates. J Med Chem. 2003; 46(24): 5171-5183. 
12. Russell RG. Bisphosphonates: mode of action and pharmacology. Pediatrics. 2007; 119(2): S150-S162.

13. Kavanagh KL, Guo K, Dunford JE, Wu X, Knapp S, Ebetino FH, Rogers MJ, Russell RG, Oppermann U. The molecular mechanism of nitrogen-containing bisphosphonates as antiosteoporosis drugs. Proc Natl Acad Sci USA. 2006; 103(20): 7829-7834.

14. https://www.uniprot.org/uniprot/C4YIE1

15. https://www.uniprot.org/uniprot/Q4QBL1

16. Altschul SF, Gish W, Miller W, Myers EW, Lipman DJ. Basic local alignment search tool. J Mol Biol. 1990; 215(3): 403-410.

17. Waterhouse A, Bertoni M, Bienert S, Studer G, Tauriello G, Gumienny R, Heer FT, de Beer TAP, Rempfer C, Bordoli L, Lepore R, Schwede T. SWISS-MODEL: homology modelling of protein structures and complexes. Nucleic Acids Res. 2018; 46(W1): W296-W303.

18. Camacho C, Coulouris G, Avagyan V, Ma N, Papadopoulos J, Bealer K, Madden TL. BLAST+: architecture and applications. BMC Bioinformatics. 2009; 10: 421.

19. Remmert M, Biegert A, Hauser A, Söding J. HHblits: lightning-fast iterative protein sequence searching by HMM-HMM alignment. Nat Methods. 2011; 9(2): 173-175.

20. Colovos C, Yeates TO. Verification of protein structures: patterns of nonbonded atomic interactions. Protein Sci. 1993; 2(9): 1511-1519.

21. Laskowski RA, MacArthur MW, Moss DS, Thornton JM. PROCHECK - a program to check the stereochemical quality of protein structures. J App Cryst. 1993; 26(2): 283-291.

22. Semenyuta I, Kovalishyn V, Tanchuk V, Pilyo S, Zyabrev V, Blagodatnyy V, Trokhimenko O, Brovarets V, Metelytsia L. 1,3-Oxazole derivatives as potential anticancer agents: Computer modeling and experimental study. Comput Biol Chem. 2016; 65: 8-15.

23. Kachaeva MV, Hodyna DM, Semenyuta IV, Pilyo SG, Prokopenko VM, Kovalishyn VV, Metelytsia LO, Brovarets VS. Design, synthesis and evaluation of novel sulfonamides as potential anticancer agents. Comput Biol Chem. 2018; 74: 294-303.

24. Sanner MF. Python: a programming language for software integration and development. $J \mathrm{Mol}$ Graph Model. 1999; 17(1):5 7-61.

25. Dassault Systèmes BIOVIA, Discovery Studio, 2.5.5, San Diego: Dassault Systèmes, 2019.

26. http://www.rcsb.org/structure/4K10

27. ChemAxon MarvinSketch, 5.3.735. http://www. chemaxon.com, 2019.

28. Hanwell MD, Curtis DE, Lonie DC, Vandermeersch T, Zurek E, Hutchison GR. Avogadro: an advanced semantic chemical editor, visualization, and analysis platform. J Cheminform. 2012; 4(1): 17.

29. Trott O, Olson AJ. AutoDock Vina: improving the speed and accuracy of docking with a new scoring function, efficient optimization, and multithreading. J Comput Chem. 2010; 31(2): 455-461. 